\title{
Non-Soviet Perspectives on the Great Famine: A Comparative Analysis of British, Italian, Polish, and German Sources
}

\author{
Paolo Fonzi ${ }^{\star}$ \\ Institut für Geschichtswissenschaften, Humboldt Universität, Berlin, Germany \\ *Corresponding author. Email: fonzipao@hu-berlin.de
}

\begin{abstract}
The present contribution analyzes systematically diplomatic reports written by German, Italian, British, and Polish representatives in the Soviet Union at the time of the Great Famine. Based on both published documents and unpublished archival sources, the article examines comparatively the perception of the Great Famine in these four countries. After providing a short overview of the diplomatic relations between the Soviet Union and the four countries at the time of the famine, this article examines how German, Italian, British, and Polish diplomats explained three key issues for understanding the Great Famine: (1) the role of the conflicts between state and peasantry in unleashing the famine; (2) the issue of whether the Soviet government intentionally caused the famine; and (3) the role of intentions in the development of the famine and the relationship between the nationalities policy of the Soviet government and the famine.
\end{abstract}

Keywords: Soviet famines; foreign relations of the Soviet Union; image of the Soviet Union abroad; Soviet nationalities policy

Non-Soviet documents have been used in many instances as a source to study the catastrophic famine that hit several areas of the USSR, especially in Kazakhstan, Ukraine, and North Caucasus, in 1931-1933. These documents were particularly important in the 1990s before the partial opening of the Soviet archives. The US Commission on the Ukraine Famine, established in 1985, made heavy use of such sources (USA Commission on the Ukraine Famine 1988). The first comprehensive account of the famine, Robert Conquest's classic The Harvest of Sorrow, published in 1986, made scattered use of British diplomatic reports (Conquest 1986). ${ }^{1}$ Not surprisingly, given the scarcity of direct sources available at that time, historians keenly sought to trace and publish foreign diplomatic reports, as these provided information otherwise not available at that time. British Foreign Office records were published two years after Conquest's book (Carynnyk, Luciuk, and Kordan 1988). In the same year a number of reports from the German Foreign Office archives, published by Dmytro Zlepko, revealed how detailed the information was that German institutions received about the unfolding of the famine (Zlepko 1988). ${ }^{2}$ Similarly, Italian diplomatic reports, published by Andrea Graziosi in 1989, were telling regarding the extent of knowledge about the famine among the Italian political elite, providing a "perspective from below" that was lacking in the then-available Soviet state sources (Graziosi 1991). ${ }^{3}$

This is an updated version of the original article. For details please see the notice at https://doi.org/10.1017/nps.2020.55 
But the archival revolution of the 1990s has not deprived these non-Soviet sources of value. In recent years, sources from other countries, including Poland, Romania, and the Vatican, have also been published or studied (Basciani 2011; Bruski 2008; McVay and Lucyuk 2011). Indeed, foreign reports have maintained their value as historical sources.

Foreigners had a peculiar perspective on the events because they tried to gather information from private contacts, from Soviet civil servants to peasants. ${ }^{4}$ Non-Soviet documents also help elucidate the perception of the famine by foreign observers (Conquest 1986, 308-321). Perceptions of the famine are to be regarded as part and parcel of the history of the famine itself. Occurrences of mass violence in the age of human rights are inevitably bound to elicit foreign intervention, be it in the form of mobilization of public opinion or that of political or military intervention. ${ }^{5}$ The Soviet famines of 1931-1933 are no exception, as in many countries public opinion pressed governments to exert diplomatic pressure to force the Soviets to admit to the existence of the famine. Analyzing which categories foreign observers employed in making sense of the famine can enhance our understanding of why non-Soviet decision makers nevertheless decide not to undertake such a policy. True, the main reason for their silence was foreign policy concerns, namely the intent of keeping good relations with the Soviet Union. Yet, further factors should be taken into account, such as patterns of perception of the Russian and the Soviet world, which co-determined foreign observers' knowledge and explanations of the Great Famine (see, for example, Engermann 2000). By systematically comparing some of the existing non-Soviet sources on the famine, namely Italian, German, British, and Polish diplomatic sources, and less systematically those of other countries, this article will inquire into such cultural patterns. In the first section, it will provide an assessment of the relations between Germany, Italy, Great Britain, Poland, and the Soviet Union at the time of the famine. Subsequently, it will analyze how diplomatic sources answer key issues for understanding the famine.

\section{Germany, Italy, Great Britain, Poland, and the Soviet Union, 1932-1933}

All countries under scrutiny had diplomatic relations with the Soviet Union when the famine occurred, though with different intensities and outlooks. Early on, since the signing of the Treaty of Rapallo in 1922, Germany had established intense collaboration in the political, economic, and military field with the Soviet Union. Such relations still existed when the collectivization was launched, though they were undergoing their first signs of strain. The National Socialists' rise to power in January 1933 would change this situation, resulting in increasing tension between Germany and the Soviet Union. Yet, only with a great deal of hindsight can we regard the year 1933 as a watershed in foreign relations. In the first period of its rule, the Nazi leadership was considerably restrained in declaring and pursuing its foreign policy goals. Therefore, many still had hope that traditionally oriented circles might mitigate it and that, therefore, Rapallo could be saved. The ratification of the Berlin Treaty in May 1933 seemed to point in this direction. Therefore, the famine occurred in a period of great uncertainty as to the state and the future of German-Soviet relations (McMurry 1979; Slutsch and Tischler 2013).

In 1932-1933, Italy was heading toward a consolidation of its ties with the USSR. Though ruled by parties with opposing ideologies, from their very start in 1924 relations between Italy and the Soviet Union were inspired by political pragmatism. Against this backdrop, the Treaty of Friendship, Non-Aggression and Neutrality signed on September 2, 1933 inaugurated a period of good relations that was to last until the Ethiopian War and the German-Italian alliance, when they underwent severe strains (Clarke 1989).

Not unlike Italy, Great Britain was consolidating its relations with the Soviet Union, after the severance of diplomatic relations between 1927 and 1929. Despite the "temporary setback" (Haslam 1983, 107-112) of Anglo-Soviet trade relations in 1932 and the Metro-Vickers affair of 1933, British-Soviet relations were heading toward normalization, spurred also by Hitler's rise to power, which brought a source of unrest to European policy (Salzmann 2003, 155-168). Among British officials, however, there were mixed feelings about the future of British-Soviet relations. "None of 
the British elite liked Soviet Russia," summarizes Kathe Neilson, "however, this did not mean that none of them was willing to co-operate with it" (Nielson 2006, 40).

Compared to the other three countries, the Second Polish Republic had the most troubled relationship with the Soviet Union since the signing of the Treaty of Riga in 1921. However, as an effect of German rising nationalism and the fears of Nazi access to power, Poland felt compelled to stabilize its relations with the Soviets by signing a non-aggression pact in July 1932 (Haslam 1983, 104). According to Hans Roos, the pact opened an "enormous breach in the Rapallo policy" (Roos 1957) to which Hitler's accession to power was to put a final end, but, together with the 1934 pact with Germany, it ushered in a period of relative stabilization in Poland's foreign policy relations.

Neither Italy nor Great Britain was directly confronted with the Great Famine through a large influx of refugees. This aspect marks a considerable difference between their experiences of the Great Famine and that of countries directly bordering the Soviet Union, like Poland and Romania, for which the famine resulted immediately in the need to care for the refugees, often co-nationals, crossing the border to escape starvation. ${ }^{6}$ Although not directly bordering the Soviet Union, the Weimar Republic as well had to deal with a large amount of immigration of both German citizens and ethnic Germans forced by collectivization and famine to leave the Soviet Union (Ottmer 2015).

These aspects are relevant in order to understand the amount and quality of intelligence from the Soviet Union available to diplomats of the four countries. It can be assumed with a fair amount of certainty that Germany and Poland were better informed about Soviet internal developments than all other powers (Mick 1995; Müller 1983). At the time of the famine, Germany had seven diplomatic missions in the Soviet Union, three of which were located in Ukraine (Moscow, Leningrad, Novosibirsk, Tbilisi, Odessa, Kharkiv, and Kiew). Information delivered by local consulates to Moscow and to Berlin was gathered, as in the case of most diplomatic proxies, through an analysis of the local press and local informants. However, a consistent part of the informants of the German diplomatic corps were ethnic Germans or German citizens.

As noted by J. Bruski, Poland's intelligence from the Soviet Union was second only to that reaching the Germans. Given the key role of the Soviet Union in the foreign policy of the Second Polish Republic and the thorny Ukrainian issue, it is hardly surprising that Poland appointed very qualified personnel to its diplomatic missions in the USSR. Polish representatives in Moscow who held the post during the famine years-Stanisław Patek until 1932 and Juliusz Łukasiewicz from 1933-were diplomats experienced in Soviet affairs. ${ }^{7}$ A considerable flow of information about the famine was delivered by the commercial and the military attaché in Moscow, the latter post held by Jan Kowalewski until 1933, and by two consulates in Ukraine, in Kyiv and Kharkiv, that drew information from the numerous petitions sent to them by the local population, by traveling, and by scrutinizing a large amount of local press (Bruski 2012, 217). ${ }^{8}$ Moreover, Polish intelligence officers in Ukraine reported extensively on the famine (Snyder 2005, 109).

Like Germany and Poland, Italy had consular representations in Ukraine-one in Kharkiv, which in 1934 was transferred to Kyiv, and one in Odessa-and in the Caucasus. The small Italian community living scattered in Caucasus, with the most sizeable being in Vladikavkaz and Verbludogorskaja, played a role similar to the ethnic Germans in establishing a bridge between the consul and the local society. Consulates had a relative freedom of movement if compared to the situation of the Italian Embassy in Moscow, which Giorgio Petracchi has characterized as an "Italian island" that was for the most part segregated from the surrounding society (Petracchi 1993, 310). Italian engineers working in the USSR were several hundred in 1930, but in 1933 most of them had left the country (Petracchi 1993, 303). In comparison to Germany, Italian consuls had a lower capacity to gather intelligence from the countryside, since they had only limited direct access to the peasantry.

British reporting on Soviet internal affairs was mostly based on information gleaned by the diplomatic corps of the two proxies of Moscow and Leningrad, as no personnel was posted in peripheral areas. Historians agree in characterizing the British diplomatic corps' expertise on the Soviet Union as fairly dismal. Keith Nielson argues that whereas up to 1914 St Petersburg was one of the three most important posts in British diplomatic service, after the Bolshevik revolution, "Moscow was no longer a focal point for British diplomacy." "Therefore," he notes, "the expertise 
about Russia that had been painfully built up within the diplomatic service before 1917 had attenuated, due both to the radical change of regimes in that country and to the intermittent nature of Anglo-Soviet relations" (Nielson 2006, 24). In particular, the British diplomats who returned to the Soviet Union in 1929, after the break of diplomatic relations in 1927, found it difficult to make sense of the great changes that occurred during their absence. Most of the connections with Soviet citizens that existed before the rupture could not be reestablished by the new diplomatic corps, as its members were, with almost no exception, new to the reality of the Soviet Union. ${ }^{9}$ Sir Edmond Ovey, who, after holding minor posts in other countries, was ambassador between 1929 and 1933, regarded the Soviet Union as a "puzzling world" —an attitude strengthened by the fact that he, like most of his staff members, spoke no Russian (Neilson 2006, 25).

\section{Making Sense of the Famine: The Role of the Peasantry}

It would be misleading to expect foreign diplomats to provide a thoroughly consistent explanation of the Great Famine. Nevertheless, a synoptic analysis of the diplomatic dispatches of the four countries allows us to discern a number of common patterns and major differences between them. A common feature of Italian, German, and Polish diplomatic reports is that they clearly understood the crucial role played by the conflict between the collectivizing state and the peasants-the former carrying out modernization at breakneck speed and the latter resisting this process regarded as a second serfdom ${ }^{10}$-in the outbreak of the famine. One can characterize this view as a conflict-based conceptualization of the famine, as, like modern scholarship, ${ }^{11}$ it regards the state-peasant conflict as one of the famine's basic factors.

In June 1933, when the famine had already claimed a large number of victims, Italian Ambassador Bernardo Attolico, mapping out the geographical distribution of the famine, distinguished between three types of famine-hit areas: the first were areas of "deep impoverishment," the second were areas of real famine, and the third included regions such as the Don, Kuban, and Northern Caucasus, where an "organized famine" was afoot. According to Attolico, in the areas of the second type, the famine was the result of a "lack of interest on the part of the peasants to till a land that is no longer their own and of their opposition to surrendering the fruits of their labor to the state." In these areas, the state faced a "silent and invisible opposition that might be completely tamed and defeated only with the coming of new generations educated to the communist spirit" (Graziosi 1991, 117). It was only in the third area that, according to Attolico, a real peasant resistance, along with the defection of large sections of communist cadres, had taken place. To crush this form of resistance, the Soviet government had "rationally" employed death by starvation as a repressive means. In a similar way, Sergio Gradenigo, Italian consul in Kharkiv, devoted lengthy passages of his reports to a description of the attitude of the peasants toward the state. He reported on the violent clash between the peasants and the workers sent by the Soviet authorities to the countryside to conduct harvesting in the summer of 1933 (Graziosi 1991, 202-203).

A similar tone is to be found in the German reports. For instance, the annual report of the German Embassy in Moscow drafted by Herbert von Dirksen in January 1933 underlined that the famine was "an enormous and complex process" that needed to be explained with reference to many factors, namely the spread of parasites, adverse weather, failure of mechanization, lack of draught force and skilled personnel, poor transportation, bureaucracy, and the need for the Soviet state to build up supply stocks for the army in Manchuria. Yet, he argued, the state-peasant conflict was its true rationale:

"The Russian peasant ${ }^{12}$ refused the new economic form and announced his refusal in a Russian way-through passive resistance. Hundreds of thousands, maybe millions, of Russian peasants left the village and went to the factories or became wanderers; those who remained in the countryside did only half their work; the fields were poorly tilled; weeds got the upper hand; the poor harvest was not collected; the harvested grain was concealed; the small amount of cattle went spoiled; the total sown area decreased from 136.6 to 134.6 million ha, the grain sown area decreased from 104.7 to 99.7 million ha. ${ }^{13}$ 
Likewise, Polish diplomats saw in the resistance of the peasants to forced collectivization a key causal factor of the famine (Bruski 2008, XXII). ${ }^{14}$ In a report from September 1932, the Polish Consul in Kyiv, besides stressing the role of economic and technical factors, pointed out that, in the Kyiv, Vinnitsa, and Odessa areas, great damage to crop harvest was caused by passive resistance on the part of the peasants. The following sentences summed up what the consul believed to be the motivation of the Ukrainian peasants:

Russia completely disregards the interests and the population of Ukraine, it strips it completely of bread. Currently we do not have any means to counter this [policy]. Only passive sabotage remains, which, although it may cause hunger and lack of bread in Ukraine, may, however, contribute to creating serious difficulties or even to the collapse of the existing system. (Bruski 2008, 97)

In contrast, British sources contain only scant reference to peasant resistance and for the most part at a relatively late date. ${ }^{15}$ The attitude of the peasants toward the Soviet state and the conflicts arising from forced collectivization and crop collection were the subject of many British reports. ${ }^{16}$ Yet, peasants' resistance was never regarded as a key factor in the whole process. Compared with Italian, Polish, and German reports, British reporting on collectivization displays a "curiously bloodless texture" (Hughes 1997, 241). Amply described in many dispatches, collectivization was considered merely from an economic point of view, without paying much attention to the political and human dimensions of it. Although peasant resistance does not go completely unmentioned in these reports, ${ }^{17}$ the emphasis is rather on the economic irrationality of the collective economic system as unable to motivate the economic subjects to produce (Carynnyk, Luciuk, and Kordan 1988, 199). In this regard, a report by Third Secretary of the Embassy J. M. K. Vyvyan recounting his travels to Crimea and Ukraine in the summer of 1932 is particularly interesting. Vyvyan visited a number of farms and, although he was able to have contacts with locals, who expressed their views in a fearless and outspoken manner, he did not get a clear picture of the situation in the countryside. Significantly, his report dwelt on economic issues with only passing references to the conditions of the peasants. In a conversation with a fellow traveler on a plane back to Moscow, he remarked that "it was a pity the children were fed so extensively on bread," which his fellow denied by stressing that not even bread was available to them, allotments amounting only "to 150 gr. a day for a whole family" (Carynnyk, Luciuk, and Kordan 1988, 96). ${ }^{18}$

This difference between Italian, German, or Polish reports, on one hand, and British reports, on the other hand, can be explained by the lack of local British consulates outside the main cities that would have been able to witness directly what was occurring in the countryside. ${ }^{19}$ It is noteworthy that Italian, German, and Polish diplomats had been reporting on early peasant uprisings deriving from opposition to collectivization. ${ }^{20}$

A further reason for this difference is the cultural background of the diplomatic personnel. Since Italy and Germany were countries of late industrialization, the Italian and German elites had developed a stronger perceptiveness for agrarian issues and for the contradiction between the cities, as the centers of modernization, and the peasant world. ${ }^{21}$ The same applies even more to Poland, which, in the interwar period, still had a largely agricultural economy, not having experienced "anything like an industrial revolution on the scale of the advanced western countries" (Stachura 1998, 42). From its very foundation, the Second Polish Republic faced the urgent need to modernize the backward and overpopulated agricultural sector by means of land reform (LandauTomaszewski 1985, 39). ${ }^{22}$ As in many Eastern and Southeastern European countries between the two world wars, in Poland peasants were a political collective subject represented by parties and movements. One of the central tenets of Eastern European agrarianism in the interwar period was that "the responsibility for land and society could only be fully assumed by an independent man who owned the land that he tilled. The idea of private ownership was thus essential to Eastern European agrarianism" (Eellend 2008, 45). 
A common trait of Italian and German documents is the presence of negative stereotypes toward the peasantry, which was regarded as a hindrance to modernization. Although, as noted above, peasants were regarded as a collective subject, they were not considered a historic subject, meaning a subject capable of moving history forward, but rather as an impediment to the course of social development. ${ }^{23}$ The Italian consul in Novorossijsk, for instance, provided an expressive picture of this view. "Feeling that he has been condemned a priori to the maximum sentence," he wrote, "the peasant awaits his turn with fatalism, in doing so, aided by his indolent and passive mentality.... The peasant believes in nothing, works the least and in the worst possible way, steals as soon as he can, hides and destroys his produce instead of surrendering it spontaneously" (Graziosi 1991, d. 32, 159160). Likewise, in an earlier report, Attolico wrote:

It was only logical that the reactions, albeit only passive-the reaction most preferred by the Russian popular instinct-would not be long in coming because it was difficult to assume that such poorly cultivated multitudes would understand what was actually good in the collectivization system that was being applied to the huge and primitive swathes of Russia. (Graziosi 1991, 92)

In German sources there are many such statements. For instance, the German consul in Kharkiv wrote in December 1933 that one of the causes of the famine was that the Soviet leadership had overlooked the fact that "according to Stalin's words 'the men decide over the thing' and the question whether the 22 million Ukrainian peasants would follow him and they would show understanding and collaboration for the new collective economic form instead of their deeply rooted individualistic ideology." ${ }^{24}$ Von Dirksen's successor, Ambassador Rudolf Nadolny, went so far as to see in Soviet collectivization the only way to "lead the enormous gray mass of the Russian people out of the rigidity of stagnation and put it into progressive motion towards a higher degree of development." 25

\section{Making Sense of the Famine: The Role of Intentions}

A further recurring topic in foreign reports is the role played by intentionality in the outbreak of the famine. This issue has sparked a heated debate among modern scholars, with a faction supporting the view that the Soviet leadership purportedly unleashed the famine and another seeing it has the undesired outcome of collectivization. ${ }^{26}$ While contemporary observers generally did not see a clearcut trade-off between these two explanations, ${ }^{27}$ there are notable differences in prioritizing one over the other. Italian sources display the most pronounced tendency toward intentionalism, especially the reports written by the Italian consul in Kharkiv Sergio Gradenigo. On May 31, 1933, Gradenigo wrote for example: "There are no doubts, in fact, that this hunger derives mainly from a famine organized and designed with the intention to 'teach the peasant a lesson' " (Graziosi 1991, 168). In a later report, Gradenigo held that the distribution of the famine proved the existence of a clear policy designed to prevent the economic hardships from unleashing a popular rebellion. Fearing revolts in the cities, the Soviet government, in Gradenigo's view, had "put the main burden of the famine (for the most part intentionally engendered) on the shoulders of the Ukrainian peasants" (Graziosi 1991, 184).

In comparison to the Italian reports, German sources provide a more nuanced interpretation. In most documents, German observers held the view that the Soviet government, while not purposely causing the famine, had exploited it in order to crush the peasants' resistance. Looking retrospectively at the famine, for example, the German consul in Kharkiv noted in 1935 that "taxation of the independent peasants, pressure put on them by other means to force peasants to abide to collectivization, famine of the years 1932-33, that has been exploited [ausgenutzt] to induce the peasants to subdue to the Soviet policy, have reached their goal turning the peasants into a 'docile instrument." ${ }^{28}$ Consistent with the conflict-based view described above, most German diplomats, both in the capital and in the Ukrainian consulates, saw the 1932-1933 crisis as a struggle that the 
government had won by employing any means at its disposal, including the famine. In December 1933 the German consul in Kharkiv wrote:

The outcome of this struggle between the party and the people has demonstrated once again the great superiority of the party organization, which can rely on state power and for which millions of deaths were not too great a sacrifice for the sake of integrating [einbeziehen] the peasants into the communist system. Whether they have managed to reach this goal cannot be said as yet. ${ }^{29}$

German consuls provided critical insights into the way grain procurement was employed by the Soviet authorities to exert pressure on the individual peasants to force them to join the collectives. A 1933 report by the German consul in Kharkiv about the conditions of the ethnic Germans, based on information provided by the Germans themselves, strikes modern readers for its capacity to grasp the interplay between central decision making and local authorities.

The deficiencies in the grain procurement campaign have to be attributed to the fact that the Soviet organs in charge of collecting grain, first of all the village councils (Dorfräte), were themselves under great pressure. They were responsible for the fulfillment of the plan toward the superior instances and therefore tried to collect the necessary grain wherever they found it. When their activity did not achieve the prescribed results, they faced dismissal and deportation. At the end of a grain procurement campaign, the unsatisfactory results were attributed to sabotage by the kulaks or by other counterrevolutionary elements, or to the failure of the party organization. In case news of the discontent of the population of the countryside reached the wider public, then the blame is cast upon the executive organs that have allegedly not understood and not properly implemented the prescriptions. Yet the result was always determined by hard pressure exercised from above on the lower echelons and by their continuous attempts to achieve higher planned figures, and on the other hand by the impossibility of getting more grain than is actually available. These measures result in a generalized weakening of agriculture and the annihilation of many individual lives. ${ }^{30}$

German reports also detailed how relief in the form of sowing seeds or food to the regions hit by the famine was used as a means to impose the will of the power center on the reluctant peripheries. Otto Schiller, after traveling across Ukraine in the summer of 1933, noted that the Soviet authorities had understood how to use hunger as a means to force people to work, thus overcoming the shortage of manpower produced by the famine. In his opinion, the state used a very brutal but effective measure, by stripping the village of every last bit of grain, taking back from the kolkhoz peasants even the already distributed cereals, and to let these same cereals go back to the village in the form of sowing aid or hunger aid: "In this way, the peasant is kept under the continuous and direct threat of hunger death and he can escape it only through his work in the kolkhoz for which he receives in the evening a spare ration barely sufficient to keep him alive."31

A similar understanding of the Soviet government's strategy to conduct the harvest of summer 1933 can be found in Polish reports. For example, a report of the Polish consul in Kyiv of November 1933 noted:

I firmly believe that only by using the hunger suffered by the peasants, throwing them little scraps, as if to a hungry dog, were [the Soviet authorities] able to force them to carry the entire burden of field work, and thereafter to force those same peasants to express gratitude for their humanitarian action of feeding [the needy]. By applying systematic terror, [the Bolsheviks] were able to break the peasant mass to such a degree that, in spite of the tragic experiences of the previous year, they managed to fulfill the entire khlebosdacha plan, again taking away almost the entire crop. (Boyko 2009, 469) 
As noted by Jan Bruski, Polish representatives in the Soviet Union had different opinions on whether the famine had been intentionally unleashed or not. Stanisław Sośnicki, of the consul in Kyiv, considered the famine to be a consequence of the doctrinarian policy pursued by the Bolsheviks, whereas Jan Karszo-Siedlewski, observing that hunger was limited to the territory of Ukraine, stressed the intentional factor by noting that the "policy of the central government towards Ukraine was much more ruthless and predatory than towards neighboring provinces of the RSFSR, with the exception of the Northern Caucasus" (Bruski 2012, 223; the entire document in Bruski 2008, 295).

In British reports, one can hardly find any such assessment of the causes of the famine. Famine and fear are referred to in a report as "the principal allies of the Soviet power" (Carynnyk, Luciuk, and Kordan 1988, 25), and there is a clear perception that the Soviet government tackled the catastrophe arising out its own irrational economic policy by putting the blame on the kulak element and trying to tighten their grip on the countryside by means of increased repression (Carynnyk, Luciuk, and Kordan 1988, 196, 243-245). In British reports, however, the stress is rather on the irrationality of the communist system that had wreaked the agricultural produce, thereby cynically regarding the death of millions of people as "the normal casualties of a nation-wide operation in class warfare (a class war to end classes)" (Carynnyk, Luciuk, and Kordan 1988, 257).

German sources stand out for a further element. Almost obsessively, German reports addressed the issue of whether the famine would lead the Soviet system to collapse or if, on the contrary, internal stability would prevail. ${ }^{32}$ This insistence can be explained by the state of German-Soviet relations in 1933. In the first years of Nazi rule, many officials of the German Foreign Office, especially the "Russia experts" (Sütterlin 1994), were particularly concerned with keeping the Rapallo policy alive, as they believed that the National Socialist policy might be tamed and forced to abide in continuity with the previous foreign policy. Therefore, German diplomats keenly sought to give Berlin a reassuring picture of the internal stability of the Soviet Union, stressing that the party power had not been consistently undermined by the famine. Thus they endeavored to convince the new rulers that the Soviet Union was a factor to be reckoned with in the following years. For example, a German report from Odessa drafted at the end of 1934 describes the terrible conditions of the population. The German consul concluded:

European inferences and standards however cannot be used here. If the situation is catastrophic, as it was last winter for the most part of the population of the countryside in the Odessa region, this is not a threat for the state but only for the individual. People die. Herewith the catastrophic situation is liquidated. The state is not threatened by any danger from within."33

\section{Making Sense of the Famine: The Role of the National Question}

Many contemporary non-Soviet observers acknowledged the existence of a link between the turn in the Soviet nationality policy and the famine. ${ }^{34}$ Again, there are differences in the way diplomatic reports dealt with this issue. Italian diplomats gave particular emphasis to this aspect, expressing the view that the Soviet government had purposely used the famine to prevent the rise of a national consciousness. Gradenigo wrote in May 1933 that the deliberate unleashing of the famine had been motivated, among other reasons, by "the more or less openly acknowledged necessity or concern to denationalize the regions where the Ukrainian and German consciousness was awakening, threatening future political difficulties, and that, for the sake of the Empire's unity, should be preferably inhabited for the most part by Russians" (Graziosi 1991, 169).

Similar to the question about intentionality, also on the national issue, the view of the German diplomats was less straightforward than that of the Italians. While they acknowledged that the Soviet authorities had coupled the procurement campaign of 1933 with a struggle against separatist movements, they rather believed that the state had staged a witch hunt campaign against separatist tendencies in order to crush any resistance to its policy. Thus, German consuls expressed the belief 
that the nationalist movement was rather a bogus threat than an actual danger. This view fits with their general disregard of the role of nationalities in the internal developments of the Soviet Union and, in particular, of the Ukrainians, whom they regarded as displaying only a weak national identity. "All in all, however," wrote the German consul in Odessa in December 1933, "it is clear that the national consciousness in Russian Ukraine is still poorly developed and that the number of its spokesmen is still small. Ukraine, not considering Eastern Galicia, find itself approximately where the Slovenes or the Slovaks were one generation ago."35 To be sure, German dispatches observed a surge of nationalism in Ukraine in 1933. Yet they considered it to be only a disguised form of the opposition by local elites and peasants to the agricultural policy of Moscow. The "real national endeavors were secondary and in the first place were merely a means to an end not an end in itself. The aim was namely only to improve the situation in the country," wrote the German Consul in Kharkiv in July $1934 .{ }^{36}$ It is noteworthy that this view did not apply only to the Ukrainians but also to the Germans. Otto Schiller devoted an entire memorandum to investigating the issue of whether the famine targeted specific national groups, concluding that a comparison between mortality rates among different national groups in Ukraine did not show the existence of a national bias. German colonists had been less severely hit by the famine than Russian and Ukrainian peasants, but this was due only to the fact that prior to the famine they had accumulated relatively consistent wealth, which had allowed them to survive in greater number. "The suffering of the German peasants," he concluded in his report, "has been caused by the Soviet agricultural policy. This however is directed against the peasantry of the Soviet Union as a whole, with no regard for national differences as far as these are not linked with social and economic differences." 37

Apart from the above explanations, the preponderance of this view in German reports can also to be explained as part of the attempts of the German diplomats to keep the Rapallo policy alive. ${ }^{38}$ By foregrounding elements of stability in the country, Germans diplomats tried to convey to Berlin the impression that the Soviet Union was not heading toward collapse. In particular, these reports were intended to restrain the influence on German foreign policy of Alfred Rosenberg, who in early writings had outlined his intention to pursue a policy of fragmentation of the USSR along national lines. When the Nazis came to power, many German diplomats feared that the Nazi government would start a campaign in support of the oppressed non-Russian nationalities. ${ }^{39}$

Similar concerns were not unknown to the Italian diplomats. According to Giorgio Petracchi, whereas the Italian consuls in Ukraine expected a popular uprising spurred by a revival of Ukrainian nationalism, Ambassador Attolico in Moscow defused this idea by pointing to the strong hold the Bolsheviks had on the strings of power (Petracchi 2004, 278). ${ }^{40}$ Similar to the German diplomats, Attolico believed that the Ukrainian national movement had no real foothold in Soviet Ukraine, which convinced Mussolini that it was inconvenient for Italy to support the international campaign against the famine.

Polish representatives closely followed the Soviet nationalities policy from its very inception in 1925. They were particularly concerned by what T. Martin has called the "Piedmont Principle," or the Soviet attempt to appeal to ethnic minorities living within the borders of neighboring countries (Martin 2001, 8-9). ${ }^{41}$ Not surprisingly they were particularly attentive to the turn against nationalities in 1933, not least because it targeted Poles among others (Bruski 2008, 251-276, 304-305, 307-310, 315-323, 323-327, 433-435). ${ }^{42}$ Like the Germans, Polish diplomats often expressed the belief that the struggle against separatism was a weapon brandished by the Soviet government to break the peasant resistance rather than a goal in itself, as the Vice-Consul in Kyiv wrote in September 1933:

To sum up, in my opinion, it can be assumed that the current political authorities of Ukraine, sent here primarily to break the resistance of the Ukrainian peasants in matters of agricultural economy, having failed in this area, resorted to the usual methods in this field, namely the search for "objective reasons." The role played by the latter in this case are: 1) alleged organizations carrying out economic sabotage, often built and directed by foreign agents; 2) Secret political organizations, that use nationalist slogans and spread separatist tendencies. (Bruski 2008, 376) ${ }^{43}$ 
British reports are particularly silent on the national issue, despite the fact that British reports seem to lend more credibility to Soviet claims that a real attempt to detach Ukraine from the Soviet Union was taking place. ${ }^{44}$ A memorandum by Sir Moore Crosthwaite, contained a lengthy appraisal of the Ukrainian question. The document dwelt consistently on the prospect of a German-Polish agreement on the Polish corridor, for which, or so the British believed, Poland would be compensated by annexing parts of Ukraine or through the creation of an independent Ukraine under her control. Most likely the memorandum was drafted in view of the German-Polish approach that led to the non-aggression pact of January 1934. The drafter considered unlikely the possibility that Ukrainians might be able to reach independence on the ground that "the peasants, though many, are divided, and there is an important element in the towns whose existence depends on the continuance of the present link with Moscow" (Carynnyk, Luciuk, and Kordan 1988, 361).

\section{Conclusion: International Perception of the Soviet Union in the $1930 \mathrm{~s}$}

The analysis of non-Soviet sources on the famine indicates commonalities as well as differences. British reports show a striking blindness to several of the issues scrutinized in this article. Besides paying less attention to the state-peasant conflict, they seldom inquired their sources about the connection between the famine and the Ukrainian question, or about the intentional use of the famine by the government. German, Italian, and Polish reports, instead, display a higher degree of insight into the human action behind the scenes of collectivization.

Apart from the amount of the information available to the diplomatic corps of these countries, differences in their perception of the famine were determined by the general perception of the "Russian" or Soviet world. British perspective on the famine and on collectivization was that of a country with no direct experience of modernization conducted by means of state intervention.

Besides different historical paths of economic development, cultural proximity played a key role in determining the outlook of each country on the famine. It is not surprising that among the countries analyzed in this article, German and Polish diplomats had a particularly deep grasp of the internal dynamics of Soviet society. An obvious reason for this difference is that both countries were directly or indirectly part of the Eastern European space, with the main area of Poland being part of the Russian Empire for more than a century. Moreover, a common trait of both countries was their belonging in what L. Namier has called the "European Middle East"-a geographic space between "Central Europe and the great Russian plain" in which the existence of multiethnic empires had left behind a social structure characterized by an overlapping of social and ethnic cleavages. Being part of nation arisen out of this post-imperial historical region made Polish and German intellectuals particularly aware of its complex and multilayered nature (Graziosi 2007). ${ }^{45}$

Interestingly, all reports on the famine show a common trait: modernization of the countryside at high speed was regarded as inevitable, and hunger, through denounced as inhuman, was considered to some extent as the unavoidable "cost" of it. This derived from the general perception of Soviet collectivization among intellectual and diplomatic circles. In many British intellectual business circles, there were contrasting feelings toward the Soviet Union, including attraction and admiration toward the experiment of Soviet collectivization, especially as this seemed to provide an answer to the widespread sense of decay of the post-World War I world. A "desire for order, for system, for an escape from the chaos and meaninglessness rife in the after-war years" aroused sentiments of Russophilia in Great Britain (Northedge and Wells 1982, 146).

Contrary to a common view, negative images of the Soviet Union were not prevailing among Italian intellectuals up to 1935, when bilateral relations started worsening (Petracchi 1986). In the eyes of many Italian intellectuals, Soviet modernization showed similarities with Italy's experience, as both countries strove toward a "new order" and a "revolution," though of opposite sign. Fascist syndicalism looked with interest at the collectivization in the Soviet Union as a positive model ${ }^{46}$ and considered Italy and the Soviet Union as "one against the spirit of the bourgeoisie and plutocracy." Apart from this rather minor, although influential, current among Italian intellectuals, especially 
those who traveled the Soviet Union in those crucial years, positive and negative perceptions were strongly intermixed. Most importantly, the perception of the Soviet Union and of collectivization was inextricably connected to the view Italian intellectuals had of the USA in the same period. In fact, most of them regarded the two countries as proposing two new, though opposed, ways of modernization, largely unknown to the European tradition and meriting particular attention. A sense of admiration for the Soviet model was not uncommon and was strongly linked to the disrepute of the American model after the 1929 crisis. A common argumentative strategy in Italian writing about the Soviet Union was that of contrasting American materialism with the Soviet reality that, despite introducing American-type mechanization, had been able to keep at least a "glimmer of spirituality" (Bassignana 2000, 26; see also Quartararo 1996 and Petracchi 1993, 314-315).

A similar coexistence of negative and positive images has been noted in German writing of the Weimar and early Nazi years by Gerd Koenen (2005; see also Casteel 2007, 2015). Koenen argues that from the turn of the century, but more intensely during the First World War, German selfimage had strongly built on the opposition between Germany and the Western world. As a consequence, Germany and "Russia," which for many Germans remained synonymous with the Russian Empire and the Soviet Union, were often understood as belonging to the same spiritual world, standing in opposition to the decadent Western civilization. Not surprisingly, collectivization was regarded with a sense of admiration and without thorough condemnation by German intellectuals.

Apart from Poland, where, as noted, in the interwar years "a strong anti-industrial and antiurban outlook pervaded ethnic Polish society" (Stachura 1998, 46), the Soviet experiment of modernization was regarded as largely necessary, and the famine, though its shameless brutality was perceived as such, was regarded by foreign diplomats to some extent as the inevitable cost of modernization. As noted by Engerman with regard to intellectuals in the US,

Many commentators approved of Soviet-style industrialization while denouncing communism. Their support for Soviet efforts to modernize a "backward" nation came in spite of their recognition of the tremendous human costs entailed.... To bring about important changes, so the logic went, would entail extreme hardships and even significant loss of lifewhich the peasants, fatalistic and inured to suffering, were especially well suited to endure. (Engerman 2000, 408)

Acknowledgments. I thank Andrea Graziosi, Lubomyr Hajda, and Roman Procyk for their support and useful comments.

Financial Support. This essay is the outcome of a research project on the German sources on the Great Famine conducted between 2014 and 2016 with the support of the Ukrainian Studies Fund and the Harvard Ukrainian Research Institute.

Disclosure. Author has nothing to disclose.

\section{Notes}

1 Along with newspaper articles, books, and other sources, Conquest's study made use of the interviews collected by the Harvard Refugee Interview Project. For British reposts, see pp. 266, 280, 281.

2 Twenty-three reports are published in facsimile in this volume with a short introduction. Several of them are available in Ukrainian translation in Kudrjačenko (2008). In the following, I will refer only to the original documents found at the Foreign Ministry Archives, although some of them are available in these two editions.

3 As pointed out in the introduction to Graziosi $(1991,30)$. Part of the documents that figure in this collection had first appeared in French translation (Graziosi, 1989).

4 An instance of the first is a confidential conversation between the German Agricultural Attaché Otto Schiller and the head of the Agricultural Department of the Statistical Office (Carynnyk, 
Luciuk, and Kordan 1988, 166-168). For the second, among the countless examples, see Andrew Cairns's reports from his travels in the USSR (Carynnyk, Luciuk, and Kordan 1988, 104-166). 5 For a broad definition of the concept, beyond the mere military intervention, see Simms and Trim (2011).

6 For the way the refugee crisis was dealt with in Poland, see Wysocki and Redko (2008); for Romania, see Basciani (2009).

7 S. Patek was Foreign Minister in 1919-1920. J. Łukasiewicz was Head of the Eastern Department of the Ministry of Foreign Affairs between 1922 and 1926. Before his posting in Moscow, he had been envoy to Riga and Vienna (Bruski 2008, XVII).

8 See for example a report of the Polish consul in Kharkiv on a car trip to Moscow, where he reported on the dire state of the fields and noted the striking difference between the state of the Ukrainian countryside and that of the Russian Socialist Federative Soviet Republic (RSFSR) (Bruski 2008, 294-296). See also a report on a car trip of the consul from Karkhiv, Poltava, in which he reports on the extent of fallow areas (Bruski 2008, 92-94).

9 Most of the British diplomats working in the Soviet Union in the 1930s had previously served in posts in other countries (Hughes 1997, 223-224).

10 The expression "new serfdom" (neue Leibeigenschaft) was used by German diplomats, as, for example, in the report from Odessa, Annual report, December 6, 1933; Political Archives of the Foreign German Ministry [PA AA], Botschaft Moskau, box 349.

11 On this aspect, most contemporary scholarship, which is sharply divided on other aspects of the interpretation of the famine, agree. See Fitzpatrick (1996, 69-70), Viola (1996), and Graziosi (1996).

12 As many of his contemporaries, von Dirksen meant the word "Russian" to refer to all Slavic nationalities of the Soviet Union.

13 German Embassy in Moscow, Annual Report. The Soviet Union in 1932, January 2, 1933. PA AA, Botschaft Moskau, box 353.

14 The attitude of the peasantry toward the Soviet authorities was keenly observed by Polish intelligence, since, during the 1920s, the Polish leadership considered military intervention in Soviet Ukraine and the question of whether the Soviet peasants would support it to be of crucial importance in this regard. It is still a matter of contention among historians whether military intervention was seriously considered by Piłsudski during the Great Famine, and whether this plan was dismissed because the peasantry's will to resist seemed to be definitely crushed by the famine, as argued by Snyder $(2005,110)$, or because Poland needed to stabilize its foreign policy relations, as argued by Bruski $(2008,53)$.

15 See, for example, Ovey to Simon, November 19, 1932 and Strang to Simon, October 14, 1933 (Carynnyk, Luciuk, and Kordan 1988, 206-208, 332-338).

16 See, for example, a dispatch about the persecution of the peasants, Sir Esmond Ovey to Sir John Simon, January 14, 1933 (Carynnyk, Luciuk, and Kordan 1988, 211-213).

17 See, for example, Ovey (Moscow) to Simon, November 19, 1932, noting: "The countryside has been little influenced by Soviet attempts to achieve that transformation of the mind of man upon which the successful construction of a Socialist society depends" (Carynnyk, Luciuk, and Kordan 1988, 218).

18 See also a report on a visit of Sir Ovey to Southern Russia, May 20, 1932 (Carynnyk, Luciuk, and Kordan 1988, 10-22).

19 British diplomats seldom traveled outside the main cities. When they did so, like George Paton and John Vyvyan, they were mostly able to tour a few farms. According to Hughes, the "British diplomats based in the comparative comfort of the Moscow Embassy still found it difficult to comprehend the sheer scale of the tragedy; ironically, staff at the Foreign Office in London probably had a greater sense of the extent of the suffering, since they received reports about the famine from a large number of different sources" $(1997,244)$. 
20 For Italy, see Graziosi (1991, 69-70, 71, 156-164.) For Germany, see German Consulate in Kyiv, Hunger Riots in Volhynia, September 9, 1932, PA AA R84260; German Consulate in Odessa, Conditions of the German Colonists, March 11, 1930; German Consulate in Kyiv, The Conditions of the Ethnic German Peasants in Volhynia, April 1, 1930; German Consulate in Kharkiv, The Conditions of the German Colonists and the Struggle for Socialization in the Country, April 30, 1930, PA AA R 84285. Many German reports were based on information received from German citizens targeted by "dekulakization," on whose behalf German diplomats intervened with Soviet authorities; for Poland, see Bruski $(2012,218)$ and two reports of August 1931, one by the vice-consul in Kharkiv, reporting among other things clashes between peasants and party activists, and one by the consul on opposition of peasants to collectivization (Bruski 2008, 16-20).

21 Although difference prevailed as to the degree of industrialization achieved in the 1920s and 1930s, with Italy still having a large proportion of the population employed in the primary sector, both countries had experienced a late and speedy industrialization. Significantly, both fascism and national socialism had a strong ruralist current within their movements; for a comparison, see Corni (1987).

22 Though publicly debated, the reform failed due to the hostile attitude of sectors of the Polish society, in particular the Catholic Church, toward industrialization and the influence of large landowners.

23 A similar perception of the peasant world was held by the Bolsheviks (Viola 1996, 14-19).

24 German Consulate in Kharkiv, Annual Political Report for 1933, The Situation in Ukraine, December 11, 1933: PA AA, Botschaft Moskau, box 348; also published in Zlepko (1988, 210-244).

25 Aufzeichnung. Unser Verhältnis zu Sowjetrussland, Annex to the report "Die Gestaltung der deutsch-sowjetischen Beziehungen," January 9, 1933. PA AA R105998. It is not possible to determine the original quote von Dirksen is referring to in his report.

26 For brevity's sake, the reader is referred only to Klid and Motyl (2012).

27 This is obvious considering that the need to ascertain the relative importance of intentional or structural causes of the famine aroused much later, against the backdrop of the debate about the role of Stalin and the high leadership in the decision-making process and, more recently, on the applicability of the category of genocide to the Great Famine. This finding is much in contrast to Wheatcroft and Davies's $(2004,420)$ argument that foreign reports tend to overemphasize intentionality.

28 German Consulate in Kharkiv, Annual Political Report, December 6, 1935. PA AA Moskau 348.

29 German Consulate in Kharkiv, Annual Political Report for 1933, The Situation in Ukraine, December 11, 1933: PA AA, Botschaft Moskau, box 348, also published in Zlepko (1988, 210-244). For a similar judgment by Ambassador von Dirksen, see German Embassy Moscow, Annual Report, The Soviet Union in 1933, October 30, 1933. PA AA, Botschaft Moskau, box 353. In a memoir written after the war, German consul in Kiew, Andor Hencke, articulated his and his colleagues' views on the famine as being the outcome of both intentional and unintentional factors (Hencke 1979).

30 German Consulate Kharkiv, Conditions of the Germans in the Ukraine, March 15, 1933. PA AA R84285.

31 German Agricultural Attaché in Moscow, Crop Prospects in Ukraine, July 17, 1933. PA AA R94408.

32 In Polish sources, a similar attitude toward the issue of internal stability is found. However, the Polish reports provide a rather pessimistic forecast. See Comprehensive analysis by the head of the Studies Department of Section II of the Main Staff sent to the 2nd Office concerning the situation in Ukraine, Warsaw, September 14, 1932 (Boyko 2009, 188-191).

33 German Consulate in Odessa, Annual Report, December 4, 1934, PA AA, Botschaft Moskau, box 349 . 
34 Though diverging on the specific role played by this factor in unleashing the famine, modern scholarship agrees on this point. See Martin (2001, 273-308).

35 German Consulate in Odessa, Annual report, 6 December 1933. PA AA, Boschaft Moskau, box 349.

36 German Consulate in Kharkiv, Political Mid-Year Report 1934, July 10, 1934. PA AA, Botschaft Moskau, box 351, also publ. in Zlepko (1988, 277-290).

37 German Agricultural Attaché in Moscow, The effects of the Soviet economic policy on Extension and Distribution of the Famine, July 15, 1933. PA AA R94408.

38 The same applies to Italy, which only with some reluctance later supported Ukrainian nationalist forces abroad (Petracchi 2004).

39 Contrary to this widespread expectation, the National Socialists, once in power, were not particularly keen in fostering their commitment to any such policy. Rosenberg was never really able to convince Hitler of the opportunity to support the non-Russian nationalities in the USSR, and the Führer remained rather reluctant to establish contacts with Russian émigré groups (Jacobsen 1968, 85ff).

40 Bruski $(2012,222)$ has pointed to a similar difference of views between the Polish embassy in Moscow and the Polish consulate in Kiew.

41 In just six years, from 1925 until mid-1931, the Polish consulates in Kharkiv and Kyiv devoted over 40 studies and reports to the policy of Ukrainization (Bruski 2008, XLII).

42 See Bruski 2008, Hołodomor d. 91, pp. 251-276; d. 101, pp. 304-305; d. 103, pp. 307-310; d. 106, pp. 315-323; d. 107, pp. 323-327; d. 149, pp. 433-435.

43 However, in a later report, the Polish consul in Kharkiv, J. Karszo-Siedlewski, seemed to lend credit to the actual existence of a "Ukrainian-national action" (Bruski 2008, 336).

44 As an example, see Carynnyk, Luciuk, and Kordan $(1988,355)$.

45 This observation may apply to Italy as well. However, as noted my Namier himself, "the Italians held but a narrow fringe beyond their historic ethnic settlements" (Namier 1942, quoted by Graziosi 2007, 207). Therefore, the link to the post-imperial space had a weaker impact on the formation of its national identity. As for Germany, see the insightful analysis by Dickinson (2008).

46 See the debate in the journal Critica Fascista in 1930-1931 (Clarke 1989, 83).

\section{References}

Basciani, Alberto. 2009. “La Romania e la grande carestia ucraina del 1932-1933.” Mondo Contemporaneo (2): 83-111.

Basciani, Alberto. 2011. "From Collectivization of the Great Famine: Eyewitness Statements on the Holodmor by Refugees from the Ukrainian SSR, 1930-1933.” Holodomor Studies 3: 1-27.

Bassignana, Pier Luigi. 2000. Fascisti nel paese dei Soviet. Torino: Bollati Boringhieri.

Boyko, Diana. 2009. Holodomor: The Great Famine in Ukraine 1932-1933. Warsaw: Institute of National Remembrance, Commission of the Prosecution of Crimes against the Polish Nation.

Bruski, Jan Jacek. 2008. Hołodomor 1932-1933. Wielki głód na Ukrainie w dokumentach polskiej dyplomacji $i$ wywiadu. Warszawa: Polski Instytut Spraw Międzynarodowych.

Bruski, Jan Jacek. 2012. "In Search of New Sources: Polish Diplomatic and Intelligence Reports on the Holodomor." In Holodomor and Gorta Mór. Histories, Memories and Representations of Famine in Ukraine and Ireland, edited by Christian Noack, Lindsay Janssen, and Vincent Comerford, 215-230. London: Anthem Press.

Clarke, Joseph Calvitt. 1989. Russia and Italy against Hitler: The Bolshevik-Fascist Rapprochement of the 1930s. New York: Greenwood Press.

Carynnyk, Marco, Lubomyr Y. Luciuk, and Bohdan S. Kordan, eds. 1988. The Foreign Office and the Famine: British Documents on Ukraine and the Great Famine of 1932-1933. Kingston, Ontario, Canada: Limestone Press.

Casteel, James E. 2007. “The Russian Germans in the Interwar German National Imaginary.” Central European History 40 (3): 429-466.

Casteel, James E. 2015. “Searching for the 'New World,' Finding 'Asia': The Rhetoric of Colonization in Interwar German Travel Accounts of the Soviet Union.” Cultural and Social History 12 (2): 255-272.

Conquest, Robert. 1986. The Harvest of Sorrow: Soviet Collectivization and the Terror-Famine. Oxford, UK: Oxford University Press. 
Corni, Giustavo. 1987. "La politica agraria del fascismo: Un confronto fra Italia e Germania." Studi Storici 28 (2): $385-421$.

Dickinson, Edward Ross. 2008. “The German Empire: An Empire?” History Workshop Journal 66 (1): 129-162.

Eellend, Johan. 2008. “Agrarianism and Modernization in Inter-War Eastern Europe." In Societal Change and Ideological Formation among the Rural Population of the Baltic Area 1880-1939, edited by Piotr Wawrzeniuk, 35-56. Huddinge: Södertörns högskola.

Engerman, David C. 2000. "Modernization from the Other Shore: American Observers and the Costs of Soviet Economic Development." The American Historical Review 105 (2): 383-416.

Fitzpatrick, Sheila. 1996. Stalin's Peasants: Resistance and Survival in the Russian Village After Collectivization. New York: Oxford University Press.

Graziosi, Andrea. 1989. "Lettres de Kharkov. La famine en Ukraine et dans le Caucase du Nord à travers les rapports des diplomates italiens, 1932-1934.” Cahiers du Monde russe et soviétique 30 (1): 5-106.

Graziosi, Andrea. 1991. Lettere da Kharkiv: La carestia in Ucraina e nel Caucaso del Nord nei rapporti dei diplomatici italiani, 1932-33. Torino: Einaudi.

Graziosi, Andrea. 1996. The Great Soviet Peasant War: Bolsheviks and Peasants, 1917-1933. Cambridge, MA: Harvard University Press.

Graziosi, Andrea. 2007. "Il mondo in Europa. Namier e il «Medio oriente europeo», 1815-1948." Contemporanea 10 (2): 193-229.

Haslam, Jonathan. 1983. Soviet Foreign Policy, 1930-33: The Impact of the Depression. London: Macmillan.

Hencke, Andor. 1979. Erinnerungen als Deutscher Konsul in Kiew in den Jahren 1933-1936. Munich: Ukrainische Freie Universität.

Hughes, Michael. 1997. Inside the Enigma. British Officials in Russia 1900-1939. London: The Hambledon Press

Jacobsen, Hans-Adolf. 1968. Nationalsozialistische Außenpolitik 1933-1938. Frankfurt am Main: Alfred Metzner Verlag.

Koenen, Gerd. 2005. Der Russland-Komplex: Die Deutschen und der Osten 1900-1945. München: C. H. Beck.

Klid, Bohdan, and Alexander J. Motyl, eds. 2012. The Holodomor Reader: A Sourcebook on the Famine 1932-1933 in Ukraine. Toronto: Kiyccius.

Kudrjačenko, Andrij. 2008. Holodomor v Ukrä̈ni 1932-1933 rokiv za dokumentamy polityčnoho archivu Ministerstva Zakodronnych Sprav Federatyvnoï Respubliky Nimeččyna. Kiev: Nacional'nyj Instytut Stratehičnych Doslidžen'.

Landau, Zbigniew, and Jerzy Tomaszewski. 1985. The Polish Economy in the Twentieth Century. London: Croom Helm.

Martin, Terry. 2001. The Affirmative Action Empire: Nations and Nationalism in the Soviet Union, 1923-1939. Ithaca, NY: Cornell University Press.

McMurry, Dean Scott. 1979. Deutschland und die Sowjetunion: 1933-1936: Ideologie, Machtpolitik und Wirtschaftsbeziehungen. Böhlau: Köln/Wien.

McVay, Athanasius, and Lubomyr Lucyuk. 2011. The Holy See and the Holodomor. Toronto: The Kashtan Press.

Mick, Christoph. 1995. Sowjetische Propaganda, Fünfjahresplan und deutsche Russlandpolitik 1928-1932. Stuttgart: Steiner.

Müller, Wolfgang. 1983. Russlandberichterstattung und Rapallopolitik: Deutsch-sowjetische Beziehungen, 1924-1933, im Spiegel de deutschen Presse. PhD diss., Philosophical Faculty, University of Saarbrücken.

Namier, Lewis. 1942. Conflicts: Studies in Contemporary History. London: Macmillan.

Neilson, Keith. 2006. Britain, Soviet Russia and the Collapse of the Versailles Order, 1919-1939. Cambridge, UK: Cambridge University Press.

Northedge, Frederic S., and Audrey Wells. 1982. Britain and Soviet Communism: The Impact of a Revolution. Basingstoke, UK: Macmillan.

Petracchi, Giorgio. 1986. “Il colosso dai piedi d'argilla”: l'URSS nell'immagine del fascismo.” In L'Italia e la politica di potenza in Europa (1938-1940), edited by Ennio Di Nolfo, Romain H. Rainero, and Brunello Vigezzi, 149-170. Milano: Marzorati.

Petracchi, Giorgio. 1993. Da San Pietroburgo a Mosca: La diplomazia italiana in Russia 1861-1941. Roma: Bonacci.

Petracchi, Giorgio. 2004. "Il fascismo, la diplomazia italiana e la "questione ucraina". La politica orientale dell'Italia e il problema dell'Ucraina (1933-1941)." In La morte della terra. La grande “carestia” in Ucraina nel 1932-33, edited by Gabriele De Rosa and Francesca Lomastro, 263-310. Roma: Viella.

Quartararo, Rosaria. 1996. "Roma e Mosca. L'immagine dell'Urss nella stampa fascista (1925-1935)." Storia Contemporanea 27 (3): 447-472.

Oltmer, Jochen. 2015. “'Volksdeutsche fremder Staatsangehörigkeit‘. Grenzen privilegierter Migration in der Weimarer Republik." In Handbuch Staat und Migration in Deutschland seit dem 17. Jahrhundert, edited by Jochen Oltmer, 483-502. Oldenburg: De Gruyter.

Roos, Hans. 1957. Polen und Europa: Studien zur polnischen Außenpolitik, 1931-1939. Tübingen: Mohr.

Salzmann, Stephanie. 2003. Great Britain, Germany and the Soviet Union. Rapallo and after, 1922-1934. Woodbridge, UK: The Boydell Press.

Simms, Brendan, and David J. B. Trim, eds. 2011. Humanitarian Intervention: A History. Cambridge, UK: Cambridge University Press.

Slutsch, Sergej, and Carola Tischler, eds. 2013. Deutschland und die Sowjetunion 1933-1941. Oldenburg: Oldenbourg Wissenschaftsverlag. 
Snyder, Timothy D. 2005. Sketches from a Secret War: A Polish Artist's Mission to Liberate Ukraine. New Haven, CT: Yale University Press.

Stachura, Peter. 1998. Poland Between the Wars. Basingstoke, UK: Macmillan.

Sütterlin, Ingmar. 1994. Die "Russische Abteilung" des Auswärtigen Amtes in der Weimarer Republik. Berlin: Duncker \& Humblot.

USA Commission on the Ukraine Famine. 1988. Investigation of the Ukrainian Famine: 1932-1933. Report to Congress. Washington, DC: United States Government Publishing Office.

Viola, Lynne. 1996. Peasant Rebels under Stalin: Collectivization and the Culture of Peasant Resistance. New York: Oxford University Press.

Wheatcroft, Stephen, and Robert W. Davies. 2004. The Industrialisation of Soviet Russia. Vol. 5: The Years of Hunger. Soviet Agriculture 1931-1933. Basingstoke, Hampshire, UK: Palgrave Macmillan.

Wysocki, Roman, and Philip Redko. 2008. "Reactions to the Famine in Poland." Harvard Ukrainian Studies 30 (1/4): 49-67.

Zlepko, Dmytro. 1988. Der ukrainische Hunger-Holocaust. Sonnenbühl: Verlag Helmuth Wildt.

\section{Archival Source}

Politisches Archiv - Auswärtiges Amt: R (Deutsches Reich), Botschaft Moskau.

Cite this article: Fonzi, P. 2020. Non-Soviet Perspectives on the Great Famine: A Comparative Analysis of British, Italian, Polish, and German Sources. Nationalities Papers 48: 444-459, doi:10.1017/nps.2019.27 